\title{
The Theme of Diaspora in the Novel of Jhumpa Lahiri
}

\author{
Ranjeeta Kumari \\ Research Scholar \\ University Department of English \\ Tilka Manjhi Bhagalpur University \\ Bhagalpur, Bihar, India \\ ranjeetakumari22081987@gmail.com
}

\begin{abstract}
The paper aims at throwing light on the Indian Diaspora, discussion of multiculturalism in relation to the theme of alienation, identity in the novel of Jhumpa Lahiri. The term of "Diaspora" is used to refer such people or population to leave their own homeland and settle down to another place which is so far from their own traditional homelands or indigenous territories. Jhumpa Lahiri writes about Diaspora and alienation, between the memory of homeland and the new strange land. The theme of psychology also plays a crucial role to decide the framework in the realm of Diaspora. The immigrants are in a permanent mental and emotional war between the myth and customs of the old world to which they are connected closely and freedom of the new one. In her novel, The Namesake (2004) she writes about the generation gap between immigrants, conflict of east-west beliefs, nostalgia, cultural displacement, loss of identity, alienation and despair.
\end{abstract}

Keywords: Diaspora, Identity, Multiculturalism, Alienation Immigrant. 


\section{Introduction:}

Jhumpa Lahiri is one of the most famous Indo-American writers who is one among the Diaspora writers. She belongs to the second wave of Diaspora community or in other words, we can say that the existing stream of Diaspora. The main purpose of Diaspora writing is not specific but it reflects the inner psyche of writers highlighting surroundings and circumstances in which they live and breathe leaving their native place and a sense of comparable scenario between their native land and existing strange land. "Diasporic writing often deals with a shared identity of being dislocated and is an important theme in postcolonial literature especially writings from Caribbean, Asian American and other countries. It means that national, ethnic or communal identities are constituted in the absence of a territory." (Abraham, 3) The conflict can be come across sometimes found through nostalgic sentiments and memories spent happily with dear ones. Jhumpa Lahiri writes about the deracination and displacements of the immigrants in an unknown land and outbursts her feeling expressing that Americans cannot connect all levels to a family background. Lahiri always talks about the cultural clashes and the questions of identity. She also describes some proper native characters by means of her portrayal skills with a wonderful message. The characters delineated by Jhumpa Lahiri relate the message properly what she wants to convey her readers. Sometimes these characters are inscribed with individuality and sometimes they come before us as just role player but recalling the memory and feelings for their own native people as well as nostalgic experience is the key factor which is centred round the Diaspora writers.

As a Diaspora writer, Jhumpa Lahiri has also chosen to write about the major issues of Diaspora deliberately considering and depicting the immigrants crisis of identity, cultural and racial divergence, alienation of the mind and the loss of the sense of belongingness and it seems the history of immigration is the history of feeling taken out and astray in a different 
time and space and its afterward consequences. A close study of her writings enables us to think that there is a trading going on between the expatriates and their sacrifices. They (immigrant characters in her writings) achieve an economic stability in return of losing own identity and belongingness. Majority of her literary writings is sustained with the theme of loss of self identity and self quest. Through her writings she makes a proper movement characters towards the sense of existence and a search in which inner and outer self is implied. The root of her theme lies not only in the feelings self realization but it also comprises the mannerism of the society to which her characters try to assimilate. Here it goes through a fix type of transformation where various kinds of language and culture get mingled and become something different losing the ancient features. People try to hold on the streamlines of past adopting them as integral parts and find a path to assess their spent time and elaborate the past better than the present. From psychological point of view it may be said that the gone period controls their psyche and affects their feelings and emotions. Sometimes this situation causes the state of dilemma and inner conflicts. Lahiri's writings help to understand the multi-cultural scenario and discuss about breaking the barriers of countries and the globalization which is going on around the world. She gets back to her homeland through her writings and somehow becomes the flag bearers of the society. Lahiri writes about characters who are immigrants like her own parents, the people who were born in England and America as the second generation of the immigrants and the problems and dilemmas of setting down in the new land. William Safran writes that "The writers of Indian Diaspora continue to relate personally or vicariously, to the homeland in one way or another".

When we trace back to the origin of Indian Diaspora we come to the conclusion that mostly people fly to USA and other places from their native lands due to their desire of economic betterment. It is clear that economic interests of people sometimes set the feeling of leaving the native place. Some people contrived to flee for political reasons and some people 
want to escape from religious discrimination. In due course, these migrated Indian have occupied a place of considerable privilege in the non-native land which could not have been possible to the native land.

The studies of Diaspora consist of the well-known works of renowned South-Asian writers. There are about 25 million Indians living worldwide and it makes the Indian community the second biggest Diaspora after Chinese, and it is reported by the Ministry of Overseas Indian Affairs that India could have been connected with the modern Diaspora and its existence by the arrival and rule of British Empire. The roots of Indian Diaspora in US could be founded before one hundred years when the people from the different regions of Punjab began to migrate to look for jobs in Washington's load mills and the California's large agricultural fields. Although these workers were Sikhs, they were known in the famous media as Hindu and almost from the beginning they were seen as different not comparable and equal as "most undesirable of all the eastern Asiatic races". Then after a long period the new form of Diaspora came into existence with the advent of the advanced capitalism and emergence of globalization. Similarly Indian students as well as colonists from Punjab also prepared a new framework favourable to Indian people.

According to Angelo Monaco, the new Indian Diaspora has begun to set in the country in the form South Asians and Middle East people due to the 1965 Immigrants and Naturalization Act which abolished the quota method and made the process of settling down very feasible and convenient. The major attention of that migration policy was to allure people with technical skills. Consequently thousands of people migrated from middle class Indian family for economic interests. There were highly qualified migrants in which doctors, scientists, engineers, doctoral students were included.

Jhumpa Lahiri through her writings present the agonies of migrants how they manage themselves in accordance with the existing circumstance having feeling of alienation in a new 
land where they have to leave their own mannerism and culture. Sometimes she also relates a message of getting unacquaintance and feeling of strange emotion. It is a proven fact that the isolation from one's own homeland causes an agonizing process that brings about numerous material and emotional traumas in the process of laying foundation in an alien land. In her writing Lahiri tries to make us clear about the actual condition of migrants. Her characters are controlled by the circumstances and after an interval or a period they realize the problems, the problems of being exhausted, miserable and frustrated. Here is an illustration from her well know work The Namesake that sheds a light on the agonies of migrants in an alien land:

"Being a foreigner is a sort of life-long pregnancy-A perpetual wait, a constant burden, a continuous feeling out of sorts. It is an on-going responsibility, a parenthesis in what had once been ordinary life, only to discover that previous life has vanished, replaced by something more complicated and demanding like pregnancy being a foreigner Ashima believes, is something that elicit the some curiosity from strangers, the come combination of pity and respect."

(The Namesake, 49-50)

"The Namesake" is a story of an Indian family who moves to America for best opportunities, concerning chiefly with the only son, Gogol Ganguly. In this novel, the whole family struggles to conform to the American way of life, the first problem arises here when Gogol who experiences the most difficulty, beginning with the problem of his name which is changed in his teens. Jhumpa Lahiri does a great job getting the readers into this chief character head and feeling for him as he develops in a culture and society entirely new to his parents and their attempts to keep the Indian culture true to their children. The novel of Jhumpa Lahiri's highlights the confusion, the homesickness and the loneliness of the first generation Indian in a foreign country. Lahiri explains about sensitivity to both the parent generations and children's towards both Americans and Indians. 
The novel is about the Ganguly and story of assimilation into the foreign land. Ashoke Ganguly came into US like so many professional Indians who are in the waves of the early sixty went to the US, as a part of the brain drain. The novel we get to see the trauma of being turn between two worlds by the role of the protagonist Gogol Gangoli, he is not proud of his origins. He tries so many times to escape his root to the Bengali culture. In the novel we get to see how Lahiri beautifully portrays the changes in the mind of Gogol who eventually develops sensitivity towards his family, culture and mostly with his name and also we get to see how Ashima ganguly evolves from beings a homesick housewife to a confident woman comfortable in her circumstances and finally she begum to feel home at Boston.

"The bad news is that they are told by Mr. Wilcox, compiler of hospital birth certificates, that they must choose a name for their son. For they learn that in American, a baby cannot be released from the hospital without a birth certificate. And that a birth certificate needs a name." (Lahiri, 27)

Name is a sign of identity in life. It helps to connect and communicate with one another and plays a vital role for people to know themselves. The title of Lahiri's novel "The Namesake" is a mirror to the problem Gogol Ganguly goes through just because of the name he inherited by birth. The problem of identity becomes hard when a person is ousted and cannot relate himself with any of the worlds he is living. Gogol was adapted the pet name but his parents did not know that the American system needs a particular name of the child just after the birth to register at the birth certificate and that is way due to the less knowledge of the foreign culture Ashoke and Ashima were forced to give their new born baby a name justifying the reason that Ashoka his son with the pet name Gogol with that he had an emotional attachment. After that Gogol finds it is very hard for him to continue with name which he thinks an embarrassment for him and he searches the uncommon nature of his name which creates issues in his life. According to him. 
"Smith"! They holler. "Collins"! "Wood”! Gogol is old enough to know that there is no Ganguli here. He is old enough to know that himself will be burned, not buried, that his body will occupy no plot of earth, that no stone in this country will bear his name beyond life. (Lahiri,66)

Jhumpa Lahiri is of the opinion that Immigrants fiction is something different from that of Diasporic writing because it has some motives borne with the agonies and problems of existentialism. She raises questions to system and thinks why one would get marginalized for writing about a specific theme. She thinks and writes that the writers have always tendencies to write about their own world they come from and it just happens that so many writers begin from different parts of the world and then they end up living in another, either by choice or for necessity of the situations and conditions, therefore they write about their experiences. The terms Diaspora, belongingness, exile, alienation, expatriation are very similar in meaning in the field of Diaspora writers and they hold some types of ambiguity in nature and relate about being both a displaced person and ambassador in the foreign land. New Diaspora becomes a way of culture production or it can be called a social term where it talks about mingling in a different cultures occurring mix identities. Lahiri wants to show the different types of portrait of the Diasporic life for her readers. The novel "The Namesake" discussed in the paper signifies this diversity. The readers are compelled to give a second thought among the states of the immigrant population.. The characters of Lahiri show both positivity and negativity to Diaspora's adventure. She represents the positive consequences of pliability and changing lifestyle in the life of immigrants. The characters in an unaccustomed way experience trouble because they spend life in a margined situation between two cultures. They lead the life, undergo the burdens, enjoy the happier moments and experience the fluctuations occurred in the both sides of the culture, two traditions and two ideologies that is 
the cause of identity crisis and conflicts. So they look at their former time and their own native culture and determined their future.

Again in the fiction "Going Ashore" Lahiri writes about the mother of Koushik who suffers from breast cancer. No one help her to deal with the situation. Even relatives and friends in India motivate her to deal with the conditions. After that the family decides to back in American in the way to get out of the distressing act and behavior of the native people and get some mental calm. Lahiri represents such problems to prove that the former definition of home as a field of safety and peace has changed in the Diasporic world. The immigrant experiences have got multiplicity. There are some of the migrated people can liberate themselves from the slavery of old values and traditions within the Diaspora's life and love the life and love the goodness of assimilation. Only sound communication between these two spaces can establish the positivity in the lives of the immigrants. We should not forget that past is our master and it will not be exaggeration in relating that somehow our present and future are decided by our past.

\section{Conclusion:}

The conclusion of the paper highlights the fact that Diaspora not only leads to the crossing of borders but it also signifies the journey across the little visible boundaries of time, space, ethnicity, traditional values, language etc. The Diaspora creates something a fresh and new entity. They (migrants) cannot easily renounce their past lifestyle and traditions and slowly get shifted to the past land and also play their roles between the best and worse situations. Here psyche becomes the instrument to turn the decision because our inner state of mind and heart paves the path for our future life. 


\section{Works Cited}

"Change and loss" lahiri, Jhumpa. Interview with Christopher Taylor, The Gurdian. (21 June 2008). Web. 19 June 2015

Jhumpa Lahiri: By the Book." The New York Times. The New York Times, 7 sept 2013. Web. 2 June 2015

Karthikadevi, C.G. "Diaspora experiences in Jhumpa Lahiri's Interpreter of "Maladies and Unaccustomed Earth” Language in India 15.1930-2940 (2015): 118-27 Print.

Lahiri, Jhumpa. Unaccustomed Earth. $1^{\text {st }}$ ed. New York: Afred A:Knopf, 2008.

Lahiri, Jhumpa. The Namesake. Boston: Houghton Miffin, 2003. Print.

Macwan, Hiral. "Struggle for Identity and Diaspora in Jhumpa Lahiri's The Namesake." International Journal of Humanities and social Science Invention 3.2319-7722 (2014): 45-49. Print

Monaco, Angelo. "Jhumpa Lahiri”. The Interpreter of the New Indian Diaspora.” (2015):7390. Print.

Panavelil, Abraham. "Post Colonial Dilemma in Kiran Desai's The Inheritance of Loss". IJOHMN, Vol. 3 Issue 5, Oct 2017, pp. 15-31.

Safran, William. "Diasporas in Modern Societies: Myth of Homeland and Return.” Diaspora 